
УДК 591.185 .6

DOI 10.11603/1811-2471.2020.v.i4.11756

\title{
СТРЕС-ІНДУКОВАНІ ЗМІНИ МОРФОФУНКЦІОНАЛЬНОГО СТАНУ НЕЙРОНІВ НАДЗОРОВОГО ЯДРА ГІПОТАЛАМУСА ЩУРІВ
}

\author{
๑Р. Є. Булик', Л. Я. Федонюк ${ }^{2}$, Т. С. Булик', О. В. Сметанюк ${ }^{1}$ \\ ${ }^{1}$ Буковинський державний медичний університет \\ ${ }^{2}$ Тернопільський національний медичний університет імені І. Я. Горбачевського МОз України
}

PEзЮМЕ. Рухова активність $\epsilon$ важливою властивістю тварин і людини, це одна з умов їх нормального існування та розвитку, яка залежить від рівня освітленості. Обмеження рухової активності (гіпокінезія, або іммобілізація) - потужний стресорний фактор, який викликає різноманітні патологічні процеси.

Гіпоталамус, як вищий підкірковий центр автономної (вегетативної) нервової системи, має потужний регулювальний вплив на всі життєво важливі функції організму, у тому числі й на підтримання гомеостатичної рівноваги живої системи, яка порушується в результаті діяльності стресорів, зокрема іммобілізації. У зв'язку з важливою роллю великоклітинних надзорових ядер гіпоталамуса в реалізації адаптаційних можливостей організму актуальним є вивчення характеру їх реагування при впливі на організм експериментальних тварин іммобілізаційного стресу.

Мета - вивчення впливу іммобілізаційного стресу на морфофункціональний стан надзорових ядер гіпоталамуса щурів.

Матеріал і методи. Експерименти проведені на нелінійних самцях білих щурів масою 200-220 г. Тривалий іммобілізаційний стрес моделювали шляхом утримання щурів у спеціальних пластикових клітках-пеналах впродовж 6 год щоденно 7 діб поспіль. Тварин було поділено на 2 серії досліджень, у кожній з яких забір біоматеріалу здійснювали о 14.00 і о 02.00 год із застосуванням морфофункціональних та статистичних методів дослідження.

Результати. Вивчення морфометричних характеристик нейронів надзорових ядер гіпоталамуса виявило добову динаміку показників. За стандартного світлового режиму у щурів реєстрували добовий ритм морфофункціональної активності нейронів надзорових ядер гіпоталамуса з максимумом активності в нічний час (02.00 год). При утримуванні тварин в умовах іммобілізаційного стресу о 14.00 год площа нейрона надзорових ядер гіпоталамуса сягала $(305,67 \pm 7,939)$ мкм² і була вірогідно більшою (на 9,97 \%) від аналогічної величини в контрольній групі щурів. Водночас, виявлено зростання площі його цитоплазми на 17,0 \%. Іммобілізаційний стрес призвів о 14.00 год до вірогідного зменшення концентрації РНК в ядрі на 33,1%, в ядерці та цитоплазмі нейронів надзорових ядер гіпоталамуса щодо величин контрольної групи тварин.

Утримування тварин в умовах іммобілізаційного стресу викликало більш виражені зміни морфофункціонального стану нейронів надзорових ядер гіпоталамуса о 02.00 год, ніж о 14.00 год. Так, площа ядра нейрона становила $(261,94 \pm 6,240)$ мкм² і була вірогідно меншою (на 14,3 \%) за аналогічну в контрольній групі тварин. Вказані зміни супроводжувалися зменшенням площі ядерця та цитоплазми нейрона, яка становила $(165,33 \pm 4,642)$ мкм² і була вірогідно меншою (на 24,2 \%) від такої в тварин, яких утримували за стандартного режиму освітлення. Перебування тварин за умов іммобілізаційного стресу порушувало добовий ритм морфофункціональної активності нейронів надзорових ядер гіпоталамуса. Більшу їх активність, на відміну від щурів, які перебували за звичайного освітлення, реєстрували у денний період спостереження.

Висновки. 1. За стандартного світлового режиму у щурів реєструється добовий ритм морфофункціональної активності нейронів надзорових ядер гіпоталамуса з максимумом активності в нічний час. 2. Іммобілізаційний стрес спричиняє порушення ритму морфофункціональної активності досліджуваних нейронів. 3. Утримування тварин в умовах іммобілізаційного стресу викликало більш виражені зміни морфофункціонального стану нейронів надзорових ядер гіпоталамуса о 02.00 год, ніж о 14.00 год, що супроводжувалося вірогідним зменшенням площ ядра, ядерця та цитоплазми нейрона щодо аналогічних величин у контрольній групі тварин.

КлючОВІ СЛОВА: надзорове ядро; морфофункціональний стан; іммобілізаційний стрес.

Вступ. Рухова активність є важливою властивістю тварин і людини, це одна з умов їх нормального існування і розвитку. Обмеження рухової активності (гіпокінезія, або іммобілізація) - потужний стресорний фактор, який викликає різноманітні патологічні процеси [2].

На життєдіяльність всіх організмів на Землі також впливають біологічні ритми (біоритми) (добові, сезонні тощо) коливання інтенсивності і характеру тих або інших біологічних процесів та явищ, які сприяють пристосуванню організмів до циклічних змін навколишнього середовища. На сьогодні біоритмічність визнана однією із основних властивостей усіх живих організмів. Вона $\epsilon$ важливим механізмом регуляції функцій, які забезпечують здатність організмів підтримувати гомеостаз та пристосовуватися до змін навколишнього середовища $[1,4]$.

Чергування циркадіанного (добового) циклу дня і ночі - найважливіший регулятор різноманітних фізіологічних ритмів у всіх живих організмів [6]. Винайдення понад сто років тому електрики і 
Огляди літератури, оригінальні дослідження, погляд на проблему, випадок з практики, короткі повідомлення штучного освітлення кардинально змінило як світловий режим, так і тривалість впливу світла, в тому числі на людину. Вплив світла в нічний час, що часто називають світловим забрудненням, збільшився і став суттєвою частиною сучасного способу життя, що супроводжується безліччю серйозних розладів поведінки і стану здоров'я.

Основним ритмоводієм функцій організму вважають нейроендокринну мозкову структуру шишкоподібну залозу (епіфіз мозку), яка виявлена у всіх хребетних. Разом з супрахіазматичним ядром (СХЯ) гіпоталамуса, ця залоза входить у систему так званого біологічного годинника організму, що відіграє ключову роль у механізмах «відліку внутрішнього часу» $[3,9]$. При цьому СХЯ гіпоталамуса виконує роль центрального осцилятора, що регулює підлаштування ритмів обміну речовин і енергії до ритмів освітленості як до екзогенного джерела енергії $[5,11]$.

Кодування інформації про світловий режим здійснюється за допомогою основного гормону шишкоподібної залози - мелатоніну $[1,5]$. Впливаючи на функціональну активність гіпоталамо-гіпофізарно-наднирковозалозної та статевої систем, мелатонін бере участь у регуляції циркадіанних і сезонних ритмів. Показано, що секреція мелатоніну підпорядкована чітким добовим варіаціям із мінімальним значенням вдень і максимумом близько 02.00 год [8]. Порушення світлового режиму (тривале освітлення, постійна темрява) $\epsilon$ визначальним стресором, що призводить до розвитку десинхронозу [7].

Гіпоталамус, як вищий підкірковий центр автономної (вегетативної) нервової системи, має потужний регулювальний вплив на всі життєво важливі функції організму, у тому числі й на підтримання гомеостатичної рівноваги живої системи, яка порушується в результаті діяльності стресорів, зокрема іммобілізації, постійного освітлення $[2,10]$. У зв'язку з важливою роллю великоклітинних нейросекреторних надзорових ядер гіпоталамуса в реалізації адаптаційних можливостей організму актуальним $є$ вивчення характеру їх реагування при впливі на організм експериментальних тварин іммобілізаційного стресу та ефектів мелатоніну [12].

Мета - з'ясувати вплив іммобілізаційного стресу на морфофункціональний стан надзорових ядер гіпоталамуса щурів.

Матеріал і методи дослідження. Експериментальні тварини були поділені на 2 серії досліджень, у кожній з яких забір біоматеріалу здійснювали о 14.00 і 02.00 год. Обрані терміни проведення експерименту зумовлені різною функціональною активністю шишкоподібної залози у вказані часові періоди доби.

Тварини 1-ї серії (контрольна група) перебували 7 діб за умов стандартного світлового режиму (світло з 08.00 до 20.00 год, освітленість люмінесцентними лампами на рівні кліток 500 Лк). Щурам 2-ї серії, які знаходилися за тих же умов освітлення, що й тварини 1-ї серії, моделювали тривалий іммобілізаційний стрес шляхом їх утримання впродовж 6 год у спеціальних пластикових клітках-пеналах щоденно 7 діб поспіль.

Після закінчення 7-денного експерименту наступного дня о 14.00 і о 02.00 год здійснювали виведення тварин з експерименту шляхом одномоментної декапітації під етаміналовим наркозом (40,0 мг/кг внутрішньочеревинно). Мозок тварин негайно вилучали і поміщали в 10,0% розчин формаліну в 0,1 М фосфатному буфері $(\mathrm{pH} 7,2)$ на 20 годин при кімнатній температурі. Після стандартної процедури зневоднення і просочення хлороформом і парафіном мозок заливали в парафін. Комісія з питань біомедичної етики БДМУ встановила, що всі етапи експерименту проведено з дотриманням основних положень ухвали Першого національного конгресу з біоетики «Загальні етичні принципи експериментів на тваринах» (2001р.), Конвенції Ради Європи про охорону хребетних тварин, що використовують в експериментах та інших наукових цілях (від 18.03.1986р.), Директиви ЄЕС № 609 (від 24.11.1986 р.) і наказів МОЗ України № 690 від 23.09.2009 р., № 944 від 14.12.2009 р., № 616 від 03.08.2012 р. та законів України.

Для вивчення морфометричних характеристик нейронів надзорового ядра гіпоталамуса гістологічні зрізи завтовшки 7 мкм депарафінували в ксилолі, проводили регідратацію в низхідних концентраціях етанолу (100\%, 96 \%, 70 \%), тричі відмивали у дистильованій воді і впродовж 48 год забарвлювали за методом Ейнарсона в розчині галоціанін-хромових галунів, що дозволяє виявляти нуклеїнові кислоти (здебільшого РНК) у нейронах. Потім зрізи тричі відмивали у дистильованій воді, дегідратували у висхідних концентраціях етанолу (70 \%, 96 \%, 100 \%), ксилолі і поміщали в канадський бальзам.

Морфометричний аналіз нейронів гіпоталамуса проводили на комп'ютерній системі цифрового аналізу зображення VIDAS-386 (Kontron Elektronik, Німеччина) у видимому спектрі. Зображення, що отримується на мікроскопі AXIOSKOP, за допомогою відеокамери COHU-4922 (COHU Inc., США) уводили в комп'ютерну систему цифрового аналізу зображення VIDAS-386 (Kontron Elektronik, Німеччина). Аналіз зображення проводили в напівавтоматичному режимі за допомогою пакета прикладних програм VIDAS-2.5 (Kontron Elektronik, Німеччина): інтерактивно визначали межі тіла нейрона, його ядра і ядерця. 
Огляди літератури, оригінальні дослідження, погляд на проблему, випадок з практики, короткі повідомлення

Отримані експериментальні дані обробляли на персональних комп'ютерах пакетом прикладних і статистичних програм VIDAS-2.5 (Kontron Elektronik, Німеччина) i EXCEL-2003 (Місгоsoft Согр., США). Для всіх показників розраховували значення середньої арифметичної вибірки (х), її дисперсії і помилки середньої (Sx). Для виявлення вірогідності відмінностей результатів досліджень у дослідних і контрольних групах тварин визначали коефіцієнт Стьюдента (t), після чого знаходили вірогідність відмінності вибірок (р) і довірчий інтервал середньої за таблицями розподілу Стьюдента. Вірогідними вважали значення, для яких $p<0,05$.
Результати й обговорення. При дослідженні морфометричних параметрів надзорового ядра гіпоталамуса о 14.00 год виявлено, що площа тіла нейрона складала $(273,89 \pm 4,298)$ мкм² $^{2}$ ядра $(74,47 \pm 1,262)$ мкм $^{2}$, ядерця - $(31,05 \pm 4,448)$ мкм $^{2}$ та

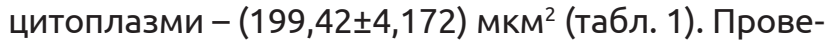
дений кореляційний аналіз встановив тісний зв'язок між площею тіла нейрона і ядра $(r=0,73)$, між площею ядра та ядерця $(r=0,95)$. Також виявлена пряма кореляційна залежність між площею нейрона і його цитоплазми $(\ulcorner=0,67)$. Ядерно-цитоплазматичне співвідношення (ЯЦС) було в межах (2,62士 $0,022)$ од, питомий об'єм ядра нейрона становив $(72,36 \pm 0,562) \%$, а цитоплазми - $(27,63 \pm 0,347) \%$.

Таблиця 1. Морфометричні зміни нейронів надзорового ядра гіпоталамуса у щурів, спричинені іммобілізаційним стресом $(\mathrm{x} \pm \mathrm{Sx})$

\begin{tabular}{|c|c|c|c|c|c|}
\hline \multicolumn{2}{|c|}{$\begin{array}{c}\text { Серії експериментальних } \\
\text { тварин }\end{array}$} & \multirow{2}{*}{$\begin{array}{c}\text { Площа нейрона, } \\
\text { мкм² }^{2} \\
273,89 \pm 4,298\end{array}$} & \multirow{2}{*}{$\begin{array}{c}\text { Площа ядра } \\
\text { нейрона, мкм² }\end{array}$} & \multirow{2}{*}{$\begin{array}{c}\text { Площа ядерця } \\
\text { нейрона, мкм² } \\
31,05 \pm 4,448\end{array}$} & \multirow{2}{*}{$\begin{array}{c}\text { Площа цитоплазми } \\
\text { нейрона, мкм² }\end{array}$} \\
\hline 1. & $\begin{array}{l}\text { Контроль, } \\
14.00 \text { год }\end{array}$ & & & & \\
\hline & $\begin{array}{l}\text { Контроль, } \\
02.00 \text { год }\end{array}$ & $\begin{array}{c}305,67 \pm 7,939 \\
p_{1}<0,01\end{array}$ & $\begin{array}{c}87,70 \pm 5,016 \\
p<0,05\end{array}$ & $36,68 \pm 8,804$ & $\begin{array}{c}217,98 \pm 5,930 \\
p_{1}<0,05\end{array}$ \\
\hline \multirow[t]{2}{*}{2.} & $\begin{array}{l}\text { Iммобілізаційний стрес, } \\
14.00 \text { год }\end{array}$ & $\begin{array}{c}301,19 \pm 7,973 \\
p<0,05\end{array}$ & $\begin{array}{c}67,85 \pm 2,690 \\
p<0,05\end{array}$ & $31,42 \pm 5,579$ & $\begin{array}{c}233,34 \pm 7,823 \\
p<0,01\end{array}$ \\
\hline & $\begin{array}{l}\text { Іммобілізаційний стрес, } \\
02.00 \text { год }\end{array}$ & $\begin{array}{c}261,94 \pm 6,240 \\
p<0,001 \\
p_{1}<0,01\end{array}$ & $\begin{array}{c}96,61 \pm 3,726 \\
p_{1}<0,001\end{array}$ & $26,82 \pm 4,290$ & $\begin{array}{c}165,33 \pm 4,642 \\
p<0,001 \\
P_{1}<0,001\end{array}$ \\
\hline
\end{tabular}

Примітка. р - вірогідні зміни щодо параметрів контрольної групи тварин того ж часового інтервалу; р $_{1}$ вірогідність різниці щодо параметрів тварин попереднього часового інтервалу в межах серії. У кожній серії по 20 тварин.

Вивчення морфометричних характеристик нейронів надзорового ядра гіпоталамуса виявило добову динаміку показників. Так, порівняно з денним періодом (14.00 год), до 02.00 год відмічали вірогідне збільшення на 11,6 \% площі тіла нейронів надзорового ядра гіпоталамуса, зумовлене зростанням площі ядра клітин на 17,8 \% (див. табл. 1), що підтверджено прямим кореляційним зв'язком ( $r=0,31)$. У свою чергу, збільшення площі ядра нейрона зумовлено зростанням площі його ядерця, яка становила $(36,68 \pm 8,804)$ мкм² $^{2}$ (див. табл. 1), коефіцієнт кореляції між досліджуваними показниками дорівнював 0,59. При цьому в нічний період спостереження ЯЦС у вазопресин-

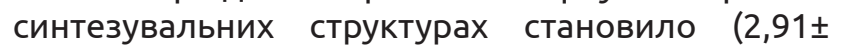
0,019) \% і було вірогідно більшим (на 11,1 \%), ніж у денний проміжок. Водночас питомий об'єм цитоплазми нейрона зростав на 2,8 \%, а ядра, навпаки, знижувався на 7,3\%.

Ці зміни поєднувалися зі зростанням концентрації РНК у самих ядрах на 13,2 \%, порівняно 3 денним періодом. При цьому вірогідних змін концентрації РНК у цитоплазмі нейрона надзорового ядра гіпоталамуса нами не зареєстровано.
Отримані величини свідчать про підвищення функціональної і синтетичної активності нейронів надзорового ядра в контрольній групі щурів у нічний період доби.

Іммобілізаційний стрес $є$ традиційною моделлю гострої стресової ситуації, при якій, крім обмеження руху, присутній і виражений емоційний компонент, пов'язаний з неможливістю уникнення загрозливої ситуації. При утримуванні тварин в умовах іммобілізаційного стресу о 14.00 год площа нейрона надзорових ядер гіпоталамуса сягала

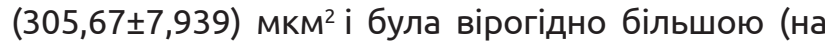
9,97 \%) за аналогічну величину в контрольній групі щурів. Водночас, нами виявлено зростання розмірів його цитоплазми на 17,0 \% $(r=0,79)$. Привертало увагу і вірогідне зростання щодо контрольної групи тварин ЯЦС на 40,8 \%, яке складало

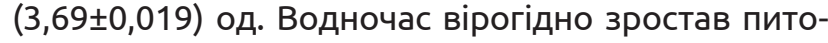
мий об'єм цитоплазми на фоні зниження питомого об'єму ядра досліджуваних нейронів. При цьому питомий об'єм ядерця перебував у межах $(10,69 \pm 1,902)$ од. і був вірогідно більшим від об'єму досліджуваної структури в нейронах контрольної групи тварин у денний період спостереження. 
Огляди літератури, оригінальні дослідження, погляд на проблему, випадок з практики, короткі повідомлення

Іммобілізаційний стрес призвів о 14.00 год до вірогідного зменшення концентрації РНК в ядрі на 33,1 \%. Подібні зміни реєстрували в ядерці та цитоплазмі досліджуваних гіпоталамічних нейронів, в яких кількість РНК вірогідна менша від величин контрольної групи тварин (табл. 2).

Таблиця 2. Добові коливання концентрації РНК у нейронах надзорового ядра гіпоталамуса щурів, що перебували в умовах іммобілізаційного стресу $(\mathrm{x} \pm \mathrm{Sx})$

\begin{tabular}{|c|c|c|c|c|}
\hline \multicolumn{2}{|r|}{$\begin{array}{c}\text { Серії } \\
\text { експериментальних тварин }\end{array}$} & $\begin{array}{c}\text { Концентрація РНК } \\
\text { в ядрі, о.о.щ. }\end{array}$ & $\begin{array}{c}\text { Концентрація РНК в } \\
\text { ядерці, о.о.щ. }\end{array}$ & $\begin{array}{c}\text { Концентрація PHK у } \\
\text { цитоплазмі, о.о.щ. }\end{array}$ \\
\hline \multirow[t]{2}{*}{1.} & $\begin{array}{l}\text { Контроль, } \\
14.00 \text { год } \\
\end{array}$ & $0,142 \pm 0,0024$ & $0,333 \pm 0,0028$ & $0,071 \pm 0,0022$ \\
\hline & $\begin{array}{l}\text { Контроль, } \\
02.00 \text { год }\end{array}$ & $\begin{array}{c}0,187 \pm 0,0077 \\
\mathrm{p}_{1}<0,001\end{array}$ & $\begin{array}{c}0,304 \pm 0,0121 \\
p_{1}<0,05\end{array}$ & $0,070 \pm 0,0037$ \\
\hline \multirow[t]{2}{*}{2.} & $\begin{array}{l}\text { Іммобілізаційний стрес, } \\
14.00 \text { год }\end{array}$ & $\begin{array}{l}0,095 \pm 0,0032 \\
p<0,001\end{array}$ & $\begin{array}{l}0,179 \pm 0,0110 \\
p<0,001\end{array}$ & $\begin{array}{l}0,038 \pm 0,0025 \\
p<0,001\end{array}$ \\
\hline & $\begin{array}{l}\text { Іммобілізаційний стрес, } \\
02.00 \text { год }\end{array}$ & $\begin{array}{c}0,109 \pm 0,0022 \\
p<0,001 \\
p_{1}<0,01\end{array}$ & $\begin{array}{c}0,253 \pm 0,0068 \\
p<0,01 \\
p_{1}<0,001\end{array}$ & $\begin{array}{c}0,065 \pm 0,0020 \\
\mathrm{p}_{1}<0,001\end{array}$ \\
\hline
\end{tabular}

Примітка: р - вірогідні зміни щодо параметрів контрольної групи тварин того ж часового інтервалу; р $_{1}$ - вірогідність різниці щодо параметрів тварин попереднього часового інтервалу в межах серії. У кожній серії по 20 тварин; о.о.щ. - одиниця оптичної щільності.

Утримування тварин в умовах іммобілізаційного стресу викликало більш виражені зміни морфофункціонального стану нейронів надзорових ядер гіпоталамуса о 02.00 год, ніж о 14.00 год. Так, площа ядра нейрона становила $(261,94 \pm 6,240)$ мкм² і була вірогідно нижчою (на 14,3 \%) за аналогічну в контрольній групі тварин. Вказані зміни супроводжувалися зменшенням площі ядерця та площі цитоплазми нейрона, яка

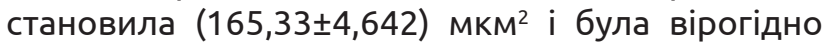
меншою (на 24,2 \%) від такої в тварин, яких утримували за стандартного режиму освітлення. Відмітимо, що перебування тварин за умов іммобілізаційного стресу порушувало добовий ритм морфофункціональної активності нейронів надзорових ядер гіпоталамуса. Більшу їх активність, на відміну від щурів, які перебували за звичайного освітлення, реєстрували у денний період спостереження (табл. 1). ЯЦС нейрона надзорових ядер гіпоталамуса о 02.00 год було вірогідно нижчим від такого в контрольній групі тварин на 39,5 \% внаслідок зменшення питомого об'єму цитоплазми нейрона досліджуваної гіпоталамічної структури.

Аналізуючи нічний етап експерименту, відзначимо, що як і у тварин, яких утримували за звичайного фотоперіоду, вищу концентрацію PHК у ядрі нейрона надзорових ядер гіпоталамуса зареєстровано також о 02.00 год на рівні $(0,109 \pm 0,0022)$ од. опт. щільності. У цьому добовому проміжку показники концентрації нуклеїнової кислоти в ядерці досліджуваних структур були нижчими за величини в контрольній групі тварин того ж часового інтервалу (табл. 2).

Порівняно з денним періодом (14.00 год), до 02.00 год виявлено зменшення площі тіла нейронів надзорових ядер гіпоталамуса, зумовлене вірогідним зменшенням площі цитоплазми клітин $(r=0,81)$. Це стало причиною зниження в нічний період спостереження ЯЦС у досліджуваних нейронах, яке становило $(1,76 \pm 0,030)$ од.

Висновки. 1. За стандартного світлового режиму у щурів реєструється добовий ритм морфофункціональної активності нейронів надзорових ядер гіпоталамуса з максимумом активності в нічний час. 2. Іммобілізаційний стрес спричиняє порушення ритму морфофункціональної активності досліджуваних нейронів. 3. Утримування тварин в умовах іммобілізаційного стресу викликало більш виражені зміни морфофункціонального стану нейронів надзорових ядер гіпоталамуса о 02.00 год, ніж о 14.00 год, що супроводжувалося вірогідним зменшенням площ ядра, ядерця та цитоплазми нейрона порівняно з аналогічними величинами в контрольній групі тварин.

Перспективи подальших досліджень. У подальшому планується досліджувати вплив екзогенного мелатоніну (гормону шишкоподібної залози) на морфофункціональну активність нейронів надзорових ядер гіпоталамуса для глибшого пізнання механізмів участі вказаних структур у регуляції нейроендокринних процесів при стресі і стрес-реактивності організму залежно від тривалості фотоперіоду. 
Огляди літератури, оригінальні дослідження, погляд на проблему, випадок з практики, короткі повідомлення ЛІТЕРАТУРА

1. Бондаренко Л. А. Пинеальная железа и гипоталамо-гипофизарно-тиреоидная система: возрастные и хронобиологические аспекты / Л. А. Бондаренко, Г. И. Губина-Вакулик, А. Р. Геворкян. - Харьков : С.А.М., 2013. 264 c.

2. Koptev M. M. Morphological substantiation for acute immobilization stress-related disorders of adaptation mechanisms / M. M. Koptev, N. I. Vynnyk // Wiadomosci Lekarskie. - 2017. - No. 70 (4). - P. 767-770

3. Bedont J. L. Constructing the suprachiasmatic nucleus: a watchmaker's perspective on the central clockworks / J. L. Bedont, S. Blackshaw // Front. Syst. Neurosci. 2015. - P. 9-74. URL : https://www.ncbi.nlm.nih.gov/pmc/ articles/PMC4424844/pdf/fnsys-09-00074.pdf DOI: $10.3389 /$ fnsys.2015.00074

4. Заморский И. И. Влияние мелатонина и эпиталамина на содержание продуктов белковой и липидной пероксидации в коре больших полушарий и гиппокампе мозга крыс в условиях острой гипоксии / И. И. Заморский, И. Ю. Сопова, В. Х. Хавинсон // Бюллетень экспериментальной биологии и медицины. - 2012. № 154 (7). - C. 59-61.

5. Extrapineal melatonin: analysis of its subcellular distribution and daily fluctuations / C. Venegas, J. A. García, G. Escames [et al.] // J. Pineal. Res. - 2012. - No. 52 (2). P. 217-227. DOI: 10.1111/j.1600-079X.2011.00931.x.

6. Kiessling $\mathrm{S}$. Light stimulates the mouse adrenal through a retinohypothalamic pathway independent of an effect on the clock in the suprachiasmatic nucleus / S. Kiessling, P. J. Sollars, G. E. Pickard // PLoS One. - 2014. No. 9 (3). - P. e92959. URL : https://www.ncbi.nlm.nih.

\section{REFERENCES}

1. Bondarenko, L.A., Gubina-Vakulik, G.I., \& Gevorkyan, A.R. (2013). Pinealnaya zheleza igipotalamo-gipofizarno-tireoidnaya sistema: vozrastnye i khronobiologicheskie aspekty [Pineal gland and hypothalamic-pituitary-thyroid system: age and chronobiological aspects]. Kharkov: S.A.M [in Russian].

2. Koptev, M.M., \& Vynnyk, N.I. (2017). Morphological substantiation for acute immobilization stress-related disorders of adaptation mechanisms. Wiadomosci Lekarskie, 70 (4), 767-770. Retrieved from: https://pubmed.ncbi.nlm. nih.gov/29064803/.

3. Bedont, J.L., \& Blackshaw, S. (2015). Constructing the suprachiasmatic nucleus: a watchmaker's perspective on the central clockworks. Front Syst. Neurosci., 9, 74. Retrieved from: https://www.ncbi.nlm.nih.gov/pmc/articles/ PMC4424844/pdf/fnsys-09-00074.pdf DOI: 10.3389/fnsys.2015.00074.

4. Zamorskiy, I.I., Sopova, I.Yu., \& Khavinson, V.Kh. (2012). Vliyanie melatonina i epitalamina na soderzhanie produktov belkovoy i lipidnoy peroksidatsii v kore bolshikh polushariy i gippokampe mozga krys v usloviyakh ostroy gipoksii [The effect of melatonin and epithalamin on the content of protein and lipid peroxidation products in the cerebral cortex and the hippocampus of rat brain in acute hypoxia]. Byulleten eksperimentalnoy biologii i meditsiny -
gov/pmc/articles/PMC3962469/pdf/pone.0092959.pdf DOI: 10.1371/journal.pone.0092959.

7. Арушанян Э.Б. Мелатонин как универсальный модулятор любых патологических процессов / Э. Б. Арушанян, Е. В. Щетинин // Патологическая физиология и экспериментальная терапия. - 2016. - №. 60 (1). - С. 79-88. DOI: https://doi.org/10.25557/0031-2991.2016.01.79-88

8. Молекулярно-клеточные механизмы пептидной регуляции синтеза мелатонина в культуре пинеалоцитов / В. Х. Хавинсон, Н. С. Линькова, И. М. Кветной [и др.] // Бюллетень экспериментальной биологии и медицины. - 2012. - № 153 (2). - С. 223-226.

9. Circadian rhythm. Dysrhythmia in the suprachiasmatic nucleus inhibits memory processing / F. Fernandez, D. Lu, P. Ha [et al.] // Science. - 2014. - No. 346 (6211). P. 854-857. DOI: 10.1126/science. 1259652

10. Bedont J. L. Patterning, specification, and differentiation in the developing hypothalamus / J. L. Bedont, E. A. Newman, S. Blackshaw // Wiley Interdiscip. Rev. Dev. Biol. - 2015. - No. 4 (5). - P. 445-468. DOI: $10.1002 /$ wdev.187.

11. Suprachiasmatic neuron numbers and rest-activity circadian rhythms in older humans / J. L. Wang, A. S. Lim, W. Y. Chiang [et al.] // Ann. Neurol. - 2015. - No. 78 (2). - P. 317-322. DOI: 10.1002/ana.24432.

12. FMA. The Supraoptic Nucleus of the Hypothalamus Modulates Autonomic, Neuroendocrine, and Behavioral Responses to Acute Restraint Stress in Rats / S. LopesAzevedo, E. A. T. Fortaleza, C. Busnardo [et al.] // Neuroendocrinology. - 2020. - No. 110. - P. 10-22. DOI: $10.1159 / 000500160$.

Bulletin of Experimental Biology and Medicine, 154 (7), 5961 [in Russian].

5. Venegas, C., García, J.A., Escames, G., Ortiz, F., López, A., Doerrier, C., et al. (2012). Extrapineal melatonin: analysis of its subcellular distribution and daily fluctuations. J. Pineal Res., 52 (2), 217-227. DOI: 10.1111/j.1600079X.2011.00931.x.

6. Kiessling, S., Sollars, P.J., \& Pickard, G.E. (2014). Light stimulates the mouse adrenal through a retinohypothalamic pathway independent of an effect on the clock in the suprachiasmatic nucleus. PLoS One, 9 (3), e92959. Retrieved from: https://www.ncbi.nlm.nih.gov/pmc/articles/ PMC3962469/pdf/pone.0092959.pdf DOI: 10.1371/journal.pone.0092959.

7. Arushanian, E.B., \& Schetinin, E.V. (2016). Melatonin kak universalnyy modulyator lyubykh patologicheskikh protsessov [Melatonin as a universal modulator of any pathological processes]. Patologicheskaya fiziologiya i eksperimentalnaya terapiya - Pathological Phisiology and Experimental Therapy, 60 (1), 79-88. DOI: https://doi.org/10.25557/00312991.2016.01.79-88 [in Russian].

8. Khavinson, V.Kh., Linkova, N.S., Kvetnoy, I.M., Kvetnaya, T.V., Polyakova, V.O., \& Korf, Kh. (2012). Molekulyarnokletochnye mekhanizmy peptidnoy regulyatsii sinteza melatonina v kulture pinealotsitov [Molecular cellular mecha- 
Огляди літератури, оригінальні дослідження, погляд на проблему, випадок з практики, короткі повідомлення nisms of peptide regulation of melatonin synthesis in pinealocyte culture]. Byulleten eksperimentalnoy biologii $i$ meditsiny - Bulletin of Experimental Biology and Medicine, 153 (2), 223-226 [in Russian].

9. Fernandez, F., Lu, D., Ha, P., Costacurta, P., Chavez, R., Heller, H.C., et al. (2014). Circadian rhythm. Dysrhythmia in the suprachiasmatic nucleus inhibits memory processing. Science, 346 (6211), 854-857. DOI: 10.1126/science.1259652

10. Bedont, J.L., Newman, E.A., \& Blackshaw, S. (2015). Patterning, specification, and differentiation in the developing hypothalamus. Wiley Interdiscip. Rev. Dev. Biol., 4 (5), 445-468. DOI:10.1002/wdev.187.

11. Wang, J.L., Lim, A.S., Chiang, W.Y., Hsieh, W.H., Lo, M.T., \& Schneider, J.A., et al. (2015). Suprachiasmatic neuron numbers and rest-activity circadian rhythms in older humans. Ann. Neurol., 78 (2), 317-322. DOI: 10.1002/ana.24432.

12. Lopes-Azevedo, S., Fortaleza, E.A.T., Busnardo, C., Scopinho, A.A., Matthiesen, M., Antunes-Rodrigues, J., \& Corrêa, F.M.A. (2020). The supraoptic nucleus of the hypothalamus modulates autonomic, neuroendocrine, and behavioral responses to acute restraint stress in rats. Neuroendocrinology, 110, 10-22. DOI:10.1159/000500160.

\title{
СТРЕСС-ИНДУЦИРОВАННЫЕ ИЗМЕНЕНИЯ МОРФОФУНКЦИОНАЛЬНОГО СОСТОЯНИЯ НЕЙРОНОВ СУПРАОПТИЧЕСКОГО ЯДРА ГИПОТАЛАМУСА КРЫС
}

๑Р. Е. Булык ${ }^{1}$, Л. Я.Федонюк' ${ }^{2}$ Т. С. Булык ${ }^{1}$ А. В. Сметанюк ${ }^{1}$

${ }^{1}$ Буковинский государственный медицинский университет

\author{
${ }^{2}$ Тернопольский национальный медицинский университет имени И. Я. Горбачевского моз Украины
}

PЕЗЮМЕ. Двигательная активность является важным свойством животных и человека, одним из условий их нормального существования и развития, зависящим от уровня освещенности. Ограничение двигательной активности (гипокинезия, или иммобилизация) - мощный стресорный фактор, который вызывает разнообразные патологические процессы.

Гипоталамус, как высший подкорковый центр автономной (вегетативной) нервной системы, оказывает мощное регулирующее влияние на все жизненно важные функции организма, в том числе и на поддержание гомеостатического равновесия живой системы, которая нарушается в результате деятельности стрессоров, в частности иммобилизации. В связи с важной ролью крупноклеточных нейронов супраоптического ядра (СОЯ) гипоталамуса в реализации адаптационных возможностей организма актуальным является изучение характера их реагирования при воздействии на организм экспериментальных животных иммобилизационного стресса (ИС).

Цель - изучить влияние иммобилизационного стресса на морфофункциональное состояние СОЯ гипоталамуса крыс.

Материал и методы. Эксперименты проведены на нелинейных самцах белых крыс массой 200-220 г. Длительный ИС моделировали путем содержания крыс в специальных пластиковых клетках-пеналах в течение 6 ч ежедневно на протяжении 7 суток. Животные были поделены на 2 серии исследований, в каждой из которых забор биоматериала осуществляли в 14.00 и 02.00 ч с применением морфофункциональных и статистических методов исследования.

Результаты. Изучение морфометрических характеристик нейронов СОЯ гипоталамуса выявило суточную динамику показателей. При стандартном световом режиме у крыс регистрируется суточный ритм морфофункциональной активности нейронов СОЯ гипоталамуса с максимумом активности в ночное время (02.00 ч). При содержании животных в условиях ИС в 14.00 ч. площадь нейрона СОЯ гипоталамуса достигала $(305,67 \pm 7,939)$ мкм² и была достоверно выше (на 9,97 \%) относительно аналогичной величины в контрольной группе крыс. В то же время отмечено увеличение площади его цитоплазмы на 17,0 \%. ИС привел в 14.00 ч к достоверному уменьшению концентрации РНК в ядре на 33,1 \%, ядрышке и цитоплазме нейронов СОЯ гипоталамуса относительно величин контрольной группы животных.

Содержание животных в условиях ИС вызвало более выраженные изменения морфофункционального состояния нейронов СОЯ гипоталамуса в 02.00 ч, чем в 14.00. Так, площадь ядра нейрона составила $(261,94 \pm 6,240)$ мкм² и была достоверно меньше (на 14,3 \%) аналогичной в контрольной группе животных. Указанные изменения сопровождались уменьшением площади ядрышка и цитоплазмы нейрона, которая составляла $(165,33 \pm 4,642)$ мкм² и была достоверно ниже (на 24,2 \%) величины у животных, содержавшихся при стандартном режиме освещения. Пребывание животных в условиях ИС нарушало суточный ритм морфофункциональной активности нейронов СОЯ гипоталамуса. Большую их активность, в отличие от крыс, находившихся при стандартном освещении, регистрировали в дневной период наблюдения.

Выводы. 1. При стандартном световом режиме у крыс регистрируется суточный ритм морфофункциональной активности нейронов СОЯ гипоталамуса с максимумом активности в ночное время. 2. ИС вызывает нарушение ритма морфофункциональной активности исследуемых нейронов. 3. Содержание животных в условиях ИС вызвало более выраженные изменения морфофункционального состояния нейронов СОЯ гипоталамуса в 02.00 ч, чем в 
Огляди літератури, оригінальні дослідження, погляд на проблему, випадок з практики, короткі повідомлення 14.00 ч, сопровождающиеся достоверным уменьшением площадей ядра, ядрышка и цитоплазмы нейрона относительно аналогичных величин в контрольной группе животных.

КЛЮЧЕВЫЕ СЛОВА: супраоптическое ядро; морфофункциональное состояние; иммобилизационный стресс.

\title{
STRESS-INDUCED CHANGES IN THE MORPHO-FUNCTIONAL STATE OF NEURONS IN SUPRAOPTIC NUCLEUS OF RAT HYPOTHALAMUS
}

\author{
@R. Ye. Bulyk', L. Ya. Fedoniuk², T. S. Bulyk' ${ }^{1}$, O. V. Smetanyuk ${ }^{1}$ \\ ${ }^{1}$ Bukovynian State Medical University, \\ 2. Horbachevsky Ternopil National Medical University
}

SUMMARY. Motor activity is an important feature of animals and humans, this is one of the conditions for their normal existence and development, which depends on the level of illumination. Restriction of motor activity (hypokinesia, or immobilization) is a powerful stress factor that can cause various pathological processes.

The hypothalamus, as the highest subcortical center of the autonomic nervous system, exerts a powerful regulating effect on all vital functions of the body, including maintaining the homeostatic balance of the living system, which is disturbed as a result of stressors, in particular immobilization. In connection with the important role of the large neurosecretory cells of the hypothalamic supraoptic nucleus (SON) in the realization of the adaptive capabilities of the organism, it is urgent to study the nature of their response when the organism of experimental animals is exposed to immobilization stress.

The aim - to learn the effect of immobilization stress on the morpho-functional state of the SON of the rat hypothalamus.

Material and Methods. The experiments were carried out on nonlinear male white rats weighing 200-220 g; immobilization stress was modeled by keeping the rats in special plastic cage-cases for 6 hours daily during 7 days.

The animals were divided into 2 series of studies, in each of which the sampling of biomaterial was carried out at 2 p.m. and 2 a.m. using morpho-functional and statistical research methods.

Results and Discussion. The study of the morphometric characteristics of the neurons of the SON of the hypothalamus revealed the diurnal dynamics of the indices. Under the standard light regime in rats, the circadian rhythm of the morpho-functional activity of the neurons of the SON was recorded with a maximum activity at night ( 2 a.m.). When the animals were kept under immobilization stress at 2 p.m., the area of the neuron of the SON of the hypothalamus reached (305.67 \pm 7.939$) \mu \mathrm{m}^{2}$ and was significantly higher (by $9.97 \%$ ) relative to the same value in intact rats. At the same time, there was an increase in the size of its cytoplasm by $17.0 \%$, and the nuclear-cytoplasmic ratio, which reached (3.69 \pm 0.019$)$ units. Immobilization stress led at 2 p.m. to a significant decrease in the RNA concentration in the nucleus by $33.1 \%$, in the nucleolus and cytoplasm of neurons of the SON of the hypothalamus relative to these values in intact animals.

Keeping animals under conditions of immobilization stress caused more pronounced changes in the morpho-functional state of the neurons of the SON of the hypothalamus at 2 a.m. rather than at 2 p.m. Thus, the area of the neuron nucleus was $(261.94 \pm 6.240) \mu \mathrm{m}^{2}$ and was significantly less (by $14.3 \%$ ) than that in intact animals. These changes were accompanied by a decrease in the area of the nucleolus and cytoplasm of the neuron, which was $(165.33 \pm 4.642) \mu \mathrm{m}^{2}$ and was significantly less (by $24.2 \%$ ) than that in animals kept under standard illumination. It was noted that the stay of animals under immobilization stress disturbed the circadian rhythm of the morpho-functional activity of the neurons of the SON of the hypothalamus. Their greater activity, in contrast to the rats under normal lighting conditions, was recorded during the daytime observation period.

Conclusions. 1. Under the standard light regime, the daily rhythm of the morpho-functional activity of the neurons of the SON with the maximum activity at night was recorded in rats. 2. Immobilization stress causes a disturbance in the rhythm of the morpho-functional activity of the studied neurons. 3. Keeping animals under conditions of immobilization stress caused more pronounced changes in the morpho-functional state of neurons in the SON of the hypothalamus at 2 a.m. than at 2 p.m., which was accompanied by a decrease in the area of the nucleus, nucleolus and cytoplasm of the neuron, which were significantly less than those in intact animals.

KEY WORDS: supraoptic nucleus; morpho-functional state; immobilization stress. 